\title{
Seston fluxes in the dam of a Colombian tropical reservoir
}

Fluxos de seston na barragem de um reservatório tropical Colombiano

\author{
Yimmy Montoya Moreno and John Jairo Ramirez \\ Institute of Biology, Antioquia University, AA 1226, Medellín, Colombia \\ e-mail: yimmymontoya3@hotmail.com, johnra77@yahoo.com
}

\begin{abstract}
Aim: Quantify sedimentation rates in Rio Grande II reservoir, his temporal fluctuation, and the degree of mineralization of the material that reaches the sediment; Methods: A system of five sedimentation traps was used to evaluate temporal variability of seston flux and the total sedimentation in the dam of Río Grande II reservoir AntioquiaColombia $\left(6^{\circ} 32,62^{\prime} \mathrm{N}, 75^{\circ} 27,27^{\prime} \mathrm{W}\right)$; Results: The flux total solids presented a mean value of $4540 \mathrm{~g} \cdot \mathrm{m}^{-2} \cdot \mathrm{d}^{-1}$ with a range oscillating between 229 and $18573 \mathrm{~g} \cdot \mathrm{m}^{-2} \cdot \mathrm{d}^{-1}$, being the fixed and suspended fraction the most of the total solids. It was evidenced that the largest fluxes were presented between the fourth and the fifth trap (the nearest to the bottom) due to hypolimnetic fluxes which contain materials of the tributaries and resuspended material. The first three traps collected particles that settled from the column of water without evaluate the overtrapping for resuspension. In some samplings the mineralization between the third and fourth trap was maximum (100\%). The fluxes of seston particles presented a mean value of $3554 \mathrm{~g} \cdot \mathrm{m}^{-2} \cdot \mathrm{d}^{-1}$ with a range between 810 and $18955 \mathrm{~g} . \mathrm{m}^{-2} \cdot \mathrm{d}^{-1}$, being predominant the inorganic fraction; Conclusions: The seston is mainly of allochthonous origin and variated in the time and in the vertical level. There was not found a significant relationship between level of the reservoir and the mixing depth with the fluxes of total sedimentation and seston; however there was relation between seston concentration and wind speed.
\end{abstract}

Keywords: seston, fluxes, tropical limnology, tropical reservoir.

Resumo: Objetivo: Quantificar taxas de sedimentação no reservatório do Rio Grande II, sua flutuação temporal, bem como o grau de mineralização do material que chega ao sedimento; Métodos: Foi utilizado um sistema de cinco armadilhas de sedimentaçáo para avaliar a variabilidade temporal do fluxo total de seston e a sedimentaçáo no reservatório Rio Grande II, Antioquia-Colombia ( $6^{\circ} 32,62^{\prime} \mathrm{N}$, $\left.75^{\circ} 27,27^{\prime} \mathrm{W}\right)$; Resultados: Fluxos de seston na barragem de um reservatório tropical Colombiano. Neste estudo os fluxos de sólidos totais apresentaram um valor médio de $4540 \mathrm{~g} \mathrm{~m}^{-2} \mathrm{~d}^{-1}$ com um intervalo entre 229 e $18573 \mathrm{~g} \mathrm{~m}^{-2} \mathrm{~d}^{-1}$, sendo a fração fixa e suspensa a maior parte dos sólidos totais. Foi evidenciado que os maiores fluxos apresentaramse entre a quarta e a quinta armadilha (as mais próximas ao fundo), devido aos fluxos hipolimnéticos que contêm materiais dos afluentes e material ressuspenso. Por isso as primeiras três armadilhas recolheram partículas que provem da coluna d'água sem avaliar o efeito real da ressuspensão. Em algumas amostragens a mineralização entre a terceira e a quarta armadilha foi máxima (100\%). O fluxo de partículas do seston apresentou um valor médio de $3554 \mathrm{~g} \mathrm{~m}^{-2} \mathrm{~d}^{-1}$, com um intervalo entre 810 e $18955 \mathrm{~g} \mathrm{~m}^{-2} \mathrm{~d}^{-1}$, sendo predominante a fração inorgânica; Conclusóes: $\mathrm{O}$ seston é principalmente de origem alóctone, variável no tempo e também no eixo vertical; não foi encontrada uma relação significativa entre o nível do reservatório e a altura da camada de mistura com os fluxos de sedimentação total e seston, no entanto, existem ligaçóes entre a concentração de seston e a velocidade do vento.

Palavras-chave: seston, fluxos, limnologia tropical, reservatório tropical. 


\section{Introduction}

Reservoirs are forced systems (Gálvez et al., 1989), acting as a hybrid between the lakes and the river that fills; for these reason a reservoir is a forced system that is always in flux and never found in equilibrium with the functions of force (Thorton et al., 1990). According to these authors, the general pattern of sedimentation is essentially the same for all reservoirs: the river with high velocity and turbulence fill a lake where the flow is slow and the load of incoming sediment is deposited differentially along the reservoir.

The variation of sedimentation rates of materials that enter and are produced in an aquatic ecosystem is evident in the sediment. This compartment accumulates material dragged (allochthonous), or produced in the same body of water (autochthonous) and mineral (evaporites, clay, stone fragments or clastic materials, minerals formed within the water) or organic origin (organisms who dying, and dead bodies fragmented, excrement, organic matter flocculated, detritus allochthonous). The composition of these materials and their speed of accumulation in the sediment express the activity of the lake basin as a receiver and as a center of biological activity (Margalef, 1983). Seston is particulate material in suspension consisting of living matter, composed of phytoplankton, zooplankton, bacteria, fungi and protozoa in one hand, and inanimate material with organic detritus, pellets and inorganic particles in suspension (tripton), in the other. Seston sedimentation is considered one of the most important variables in the models for the restoration of lentic systems. This variable can be evaluated as sediment flux $\left(\mathrm{g} \cdot \mathrm{m}^{-2} \cdot \mathrm{d}^{-1}\right)$, sedimentation speed $\left(\mathrm{m}^{\mathrm{d}} \mathrm{d}^{-1}\right)$ or removal rate $\left(\mathrm{d}^{-1}\right)$ (Imboden and Lerman, 1978).

Commonly seston flux has been studied using averages of a trap located in the deepest part of the system and near the bottom (Håkanson, 1975; Avnimelech and Vodka, 1988). However, more consistent results are obtained using several traps, which allows a better explanation of the seston dynamics (Mitamura, et al.,1990; Håkanson and Jansson, 2002). In the sediment occur biological, physical and chemical processes that influence the metabolism of all entire system. Therefore, to know his composition is of vital importance for the study of the historical development of aquatic ecosystems and the adjacent terrestrial ecosystems (Esteves, 1998).

The deposition is influenced by the size and shape of particles, temperature and decomposition processes (mineralization) suffered by particulate organic matter in her travel through the water column. It is one of the processes that govern metabolism of a lake, and that influence regeneration of epilimnetic nutrients, removal of sediment material and control the nutrient supplement to the benthic fauna (Bloesch and Uehlinger, 1986).

Since the pioneering research of Heim (1900 apud Alvarez-Cobelas et al., 1993) had been published more than 125 articles on sedimentation traps; $45 \%$ about the sea and $55 \%$ on limnetic environments. Until 1991, Blomqvist and Håkanson (1981), found nine studies that were published about methodological laboratory. This document shows that the use of sedimentation traps (Bloesch and Burns, 1980) help to identify the main trends in seston dynamics in temperate lakes (Pennington, 1974) and sea (Gardner, 1977; Wassmann et al., 1990).

Hargrave and Burns (1979) found that cylinders with a ratio $>10$ can maintain a layer of calm water above the bottom of the trap under conditions of normal flow into lakes and oceans. These authors have outlined some theoretical considerations about the effect of turbulence around and within the traps and showed that variations in the ratio height: diameter are important for the retention of the particles. A trap suitable for lakes is a simple PVC cylinder with a diameter between 5 and $20 \mathrm{~cm}$ of height with a diameter more than 5 to small lakes, and more than 10 for most turbulent water bodies (Bloesch and Burns, 1980).

In Colombia, the few studies on sedimentation had been carried in reservoirs mainly; however, Ramírez and Noreña (2001) assessed the sedimentation rates in a small urban lake. Vargas and Ramírez (2002) evaluated the spatial and temporal variations of sedimentation rates of sestonic material in the reservoir La Fe. Paeres and Rivera (2004) assessed the primary phytoplankton production and total sedimentation in Juan Amarillo wetland. Niño and Guillot (2004) studied the spatial and temporal variations of seston sedimentation rates of nitrogen and phosphorus in Neusa reservoir. They showed that sedimentation was correlated with the stability of the water column and with the release of material from the detritic necromass of Egeria densa macrophyte.

The main goal of this study was to quantify sedimentation rates in Rio Grande II reservoir, his temporal fluctuation, and the degree of mineralization of the material that reaches the sediment. 


\section{Material and Methods}

This research was conducted between April and July 2003 near the dam of Río Grande II reservoir $\left(6^{\circ} 32.62^{\prime} \mathrm{N}, 75^{\circ} 27.27^{\prime} \mathrm{W}\right)$ located in the department of Antioquia - Colombia (Figure 1). The reservoir elevation is $2270 \mathrm{~m}$ with a surface area of $1200 \mathrm{ha}$, a volume of $220 \mathrm{Mm}^{3}$, a maximum depth of $42 \mathrm{~m}$, and an average depth of $37.9 \mathrm{~m}$ and a maximum length of $10 \mathrm{~km}$. Rio Grande reservoir it located in the regional soil formation called 'batolito antioqueńo' (Montoya and Ramírez, 2007).

One survey station was localized $1 \mathrm{~km}$ near to dam, in the confluence between Grande river, Chico river (main affluent to reservoir) and Las Animas stream. In the water column was evaluated temperature and dissolved oxygen for an average of column sampling of $35 \mathrm{~m}$. The mixing depth was evaluated according to the consideration of Reynolds (1984). Additionally, it was determinated the photic depth using a Light Meter LiCor Li -250 . To make a general characterization of the water column in the work area were extracted water samples each $5 \mathrm{~m}$ from the surface to the bottom of the column. In these samples were evaluated conductivity, $\mathrm{pH}$, total solids (TS), total solids fixed (TSF), total volatile solids (TVS), total suspended solids, volatile and fixed (TSS, TVS and TSF, respectively) and total dissolved solid (TDS).

At each survey five traps were placed in different depths. These consisted in PVC cylinders with a

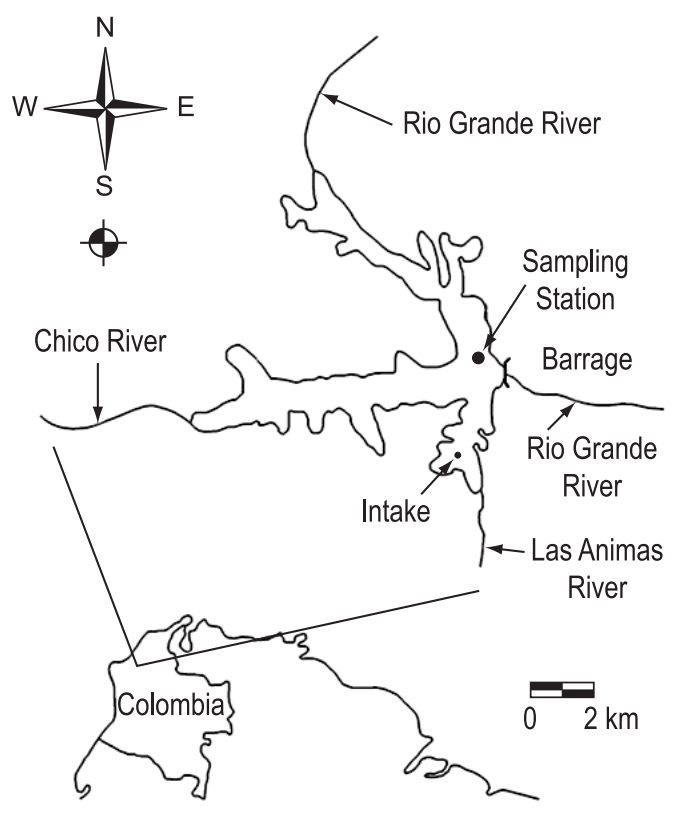

Figure 1. Location of the Río Grande II reservoir. height/diameter ratio of 7 (Bloesch and Burns, 1980), filled with water from the surface and the last trap located five meters from the bottom; the others traps were placed at intervals of five meters between them (Montoya and Ramírez, 2007). For material balance, suspended solids were not discounted of sample, because we considered that water in the trap was replaced for others of different density. Traps were exposed for ten days during a total of seven surveys. In each trap was evaluated in situ dissolved oxygen, saturation percentage and water temperature with YSI-52 oximeter. The samples were refrigerated for transportation and isn't added any type of preservative. The material settled was not corrected by effects of resuspension; therefore corresponds to total settled material.

In the water from each tube it was measured TS, TSF, TVS, TDS, TSS, TVS and TSF by gravimeter (APHA, 1995); and electrical conductivity, turbidity, $\mathrm{pH}$, dissolved inorganic carbon (DIC) (Mackereth et al., 1972). The sedimentation rate (flux) $\mathrm{g} \mathrm{m}^{-2} \mathrm{~d}^{-1}$ was established only for the TS, TSS, TVS and TSF and was calculated according to the Equation 1 in Callieri et al. (1991):

$\mathrm{SF}=\left(\mathrm{W}_{\mathrm{i}}-\mathrm{W}_{\mathrm{o}}\right) / \mathrm{AE}_{\mathrm{x}}$

where: $\mathrm{W}_{\mathrm{i}}$ is the weight $(\mathrm{g})$ of the material inside the trap $=$ volume of the trap in liters by the concentration of the particulate material in the whole trap $\left(\mathrm{mg} . \mathrm{L}^{-1}\right)$; $\mathrm{W}_{\mathrm{o}}$ is the amount of material $(\mathrm{g})$ in the upper part of the trap calculated multiplying the volume of the trap by the concentration of the particulate material outside the trap in $\mathrm{g} . \mathrm{L}^{-1} ; \mathrm{A}$ is the trap area $\left(\mathrm{m}^{2}\right) ; \mathrm{E}_{\mathrm{x}}$ is the exposure period (days).

To determine existence of significant differences in the sedimentation rates between sampling times (7) and depths (5), a block design using time as a variable block was used. The relationship between mineralization fluxes and the physical and chemical variables was performed by analysis of multiple linear regression and correlation. Statistical analyses mentioned above were carried out with the statistical package Statgraphics v. 5, 0.

\section{Results}

The environmental variables considered presented very low variability during the investigation (Table 1), which is common in tropical regions. Only air temperature presented significant differences between research periods.

The flux of materials during the experiment showed a wide variation in the time (Table 2). The total seston flux presented a mean value of 
4540 g. $\mathrm{m}^{-2} \mathrm{~d}^{-1}$ with an increase in the flux towards the last trap, very pronounced on April, May and July months, and a smaller value on June and the last sampling on July (Figure 2a). A vertical level with the increase in the depth found an increase in the material flux $(\mathrm{r}=0.87)$ with the average maximum value $\left(631 \mathrm{~g} \cdot \mathrm{m}^{-2} \cdot \mathrm{d}^{-1}\right)$ located on the fourth trap (Figure 2b).

Most of the physical and chemical variables evaluated in the water of the traps not present significant differences between depths, except for dissolved oxygen and saturation percentage, water temperature, $\mathrm{pH}$ and turbidity. At temporal level, significant differences were found only for dissolved oxygen and saturation percentage, water temperature and electrical conductivity (Table 3). In the same table, the ANOVA determined that the majority of material fluxes showed significant differences at the time and vertical profile except for TDS. In general there are significant differences between samples which are associated with the variation of the thermal profile of the reservoir and the oscillation of the mixing depth, caused by the strong winds that occur in the area, despite this water column showed a stable thermal stratification since last May to end sampling on July (Figure 3).

Seston sedimentation introduced temporal variation showed as an increase in the flux between the first and the third survey, with respect to the remaining samples (Figure 4a). There are apparent differences at vertical level, between the first and fourth trap (Figure 4b). Seston fluxes have a significant relation with wind speed $(\mathrm{r}=0.55, \mathrm{p}=0.0012)$ but not with discharge $(\mathrm{r}=0.26, \mathrm{p}=0.15)$.

The temporal and vertical variation of inorganic material (Figure 5a, b) showed a mean value of $2626.7 \mathrm{~g} \cdot \mathrm{m}^{-2} \cdot \mathrm{d}^{-1}$, oscillating at the time and vertical profile, showing a proportional increase in the flux of inorganic material with the increase in depth $(r=0.97)$. The relationship between organic and inorganic material evidenced at temporal level a high mineralization, as in the first sampling the relationship bioseston/abioseston was less than one. In the samplings 5 and 7 the relationship was inverse (Figure 6a, b).

The mixing depth and the reservoir level presented lower relationship with changes in seston and Total Solids concentration (Figure 7a, b, c, d).

Table 1. Exploratory analysis of climatic information in Río Grande II reservoir.

\begin{tabular}{lccccccc}
\hline \multicolumn{1}{c}{ Climatic variable } & Average & Standard deviation & Minimum & Maximum & Range & C.V & $p$ \\
\hline Wind speed $\left(\mathrm{m} \mathrm{s}^{-1}\right)$ & 4.69 & 0.72 & 3.39 & 5.84 & 2.45 & 15.7 & 0.72 \\
Air temperature $\left({ }^{\circ} \mathrm{C}\right)$ & 18.0 & 1.1 & 16 & 20 & 4 & 6.1 & 0.0151 \\
Precipitation $(\mathrm{mm} /$ day $)$ & 5.1 & 0.3 & 0 & 43.2 & 43.2 & 5.9 & 0.012 \\
Attenuation coefficient $\left(\mathrm{m}^{-1}\right)$ & -1.21 & 0.19 & -1.49 & -0.82 & 0.67 & 16.9 & 0.15 \\
$1 \%$ extinction $(\mathrm{m})$ & 3.8 & 0.8 & 3 & 5.61 & 2.61 & 19.7 & 0.183 \\
\hline
\end{tabular}

Table 2. Results of the exploratory analysis of information collected in the sedimentation experiment.

\begin{tabular}{|c|c|c|c|c|}
\hline Variable & Average & Minimum & Maximum & C.V \\
\hline Oxygen $\left(m g \cdot L^{-1}\right)$ & 2.31 & 0.63 & 6.06 & 57.2 \\
\hline Oxygen Saturation (\%) & 25.03 & 6.9 & 68.5 & 58.8 \\
\hline Temperature $\left({ }^{\circ} \mathrm{C}\right)$ & 18.7 & 17.1 & 21.6 & 5.8 \\
\hline Conductivity $\left(\mu S . \mathrm{cm}^{-1}\right)$ & 248.7 & 202 & 345 & 12.8 \\
\hline $\mathrm{pH}$ (pH units) & 6.78 & 6.29 & 9.45 & 10.05 \\
\hline Turbidity (NTU) & 280.5 & 0 & 1000 & 81 \\
\hline Outflow $\left(\mathrm{m}^{3} \mathrm{~s}^{-1}\right)$ & 7 & 2.76 & 3.2 & 39.4 \\
\hline $\mathrm{TS}\left(\mathrm{mg} \cdot \mathrm{L}^{-1}\right)$ & 4540.2 & 229 & 18573 & 88.3 \\
\hline $\mathrm{TSF}\left(\mathrm{mg} \cdot \mathrm{L}^{-1}\right)$ & 3548.9 & 0 & 15223 & 96.6 \\
\hline TVS (mg. $\left.\mathrm{L}^{-1}\right)$ & 1038.19 & 89 & 3338 & 74 \\
\hline $\mathrm{SS}\left(\mathrm{mg} \cdot \mathrm{L}^{-1}\right)$ & 3353.7 & 810 & 18955 & 107.4 \\
\hline $\mathrm{FSS}\left(\mathrm{mg} \cdot \mathrm{L}^{-1}\right)$ & 2626.6 & 148 & 12420 & 105 \\
\hline $\operatorname{VSS}\left(\mathrm{mg} \cdot \mathrm{L}^{-1}\right)$ & 1086.2 & 0 & 12118 & 191.6 \\
\hline $\mathrm{DS}\left(\mathrm{mg} \cdot \mathrm{L}^{-1}\right)$ & 1066 & 0 & 6650 & 144 \\
\hline $\mathrm{DIC}\left(\mathrm{mmol} \cdot \mathrm{L}^{-1}\right)$ & 0.441 & 0.157 & 3.61 & 134.8 \\
\hline
\end{tabular}


Table 3. Variance analysis of chemical and physical variables an material fluxes.

\begin{tabular}{|c|c|c|c|c|}
\hline Variable & Factor & $\mathrm{F}$ & $\mathrm{p}$ & Average difference \\
\hline \multirow[t]{2}{*}{ Oxygen dissolved (mg. $\left.\mathrm{L}^{-1}\right)$} & Surveys & 3,74 & 0,0109 & $1-4,1-6,1-7$ \\
\hline & Depths & 10,326 & 0,0001 & $1-2,1-3,1-4,2-3,2-4,2-5$, \\
\hline \multirow[t]{2}{*}{ Oxygen saturation (\%) } & Surveys & 3,75 & 0,0109 & $1-4,1-6,1-7$ \\
\hline & Depths & 10,73 & 0,0001 & $1-2,1-3,1-4,2-3,2-4,2-5$, \\
\hline \multirow[t]{2}{*}{$\mathrm{pH}$ (pH units) } & Surveys & 2,39 & 0,0643 & n.s \\
\hline & Depths & 5,19 & 0,0046 & $1-2,1-3,1-4,1-5$ \\
\hline \multirow[t]{2}{*}{$\mathrm{DIC}\left(\mathrm{mmol} . \mathrm{L}^{-1}\right)$} & Surveys & 1,009 & 0,446 & n.s \\
\hline & Depths & 0,667 & 0,6223 & n.s \\
\hline \multirow[t]{2}{*}{ Temperature $\left({ }^{\circ} \mathrm{C}\right)$} & Surveys & 27,76 & 0,0000 & $1-2,1-3,1-4$ \\
\hline & Depths & 21,92 & 0,0000 & $1-2,1-3,1-4,2-3,2-4,2-5$, \\
\hline \multirow[t]{2}{*}{ Conductivity $\left(\mu \mathrm{S} . \mathrm{cm}^{-1}\right)$} & Surveys & 4,019 & 0,0078 & $1-4,1-7$ \\
\hline & Depths & 0,245 & 0,9098 & n.s \\
\hline \multirow[t]{2}{*}{ Turbidity (NTU) } & Surveys & 0,85 & 0,545 & n.s \\
\hline & Depths & 5,41 & 0,0037 & $1-5,2-5$ \\
\hline \multirow[t]{2}{*}{ Total solids fluxes $\left(\mathrm{g} \mathrm{m}^{-2} \mathrm{~d}^{-1}\right)$} & Surveys & 3,55 & 0,0139 & $1-3$ \\
\hline & Depths & 4,67 & 0,0074 & $1-4,1-5,2-4,2-5,3-4$ \\
\hline \multirow[t]{2}{*}{ Total suspended solids fluxes $\left(\mathrm{g} \mathrm{m}^{-2} \mathrm{~d}^{-1}\right)$} & Surveys & 2,98 & 0,0287 & $1-3$ \\
\hline & Depths & 2,83 & 0,0505 & $1-4,1-5,2-5$ \\
\hline \multirow[t]{2}{*}{ Fixed suspended solids fluxes $\left(\mathrm{g} \mathrm{m}^{-2} \mathrm{~d}^{-1}\right)$} & Surveys & 4,67 & 0,0036 & $1-3,1-7$ \\
\hline & Depths & 3,18 & 0,0344 & $1-4,1-5,2-5$ \\
\hline \multirow[t]{2}{*}{ Volatile suspended solids fluxes $\left(\mathrm{g} \mathrm{m}^{-2} \mathrm{~d}^{-1}\right)$} & Surveys & 1,26 & 0,3184 & $1-3$ \\
\hline & Depths & 1,52 & 0,2327 & $1-4$ \\
\hline
\end{tabular}

n.s. $=$ Not significant.

\section{Discussion}

Among the environmental variables considered only the air temperature presented significant differences between periods of investigation, which is attributable to the extent of the sampling period, since the early collections are, for the season with a greater tendency to rain, the following to a period of transition and the last time a sampling warm.

The total solids appear in a greater concentration in the early period of stratification, with less value in the warm surface waters. At present, a model of hypolimnetic vertical flow showed the higher values occurring in the traps located closest to the bottom, which exhibit values up to three times higher than those of most surface traps.

Seston sedimentation found in the Rio Grande II reservoir is higher compared with other tropical reservoirs (Vargas and Ramírez, 2002; Maricato, 1994) and reservoirs in temperate zones (AlvarezCobelas et al. 1993) which is attributable to big size of the basin $\left(1054 \mathrm{~km}^{2}\right)$ compared to the area of the reservoir $\left(12 \mathrm{~km}^{2}\right)$, which implies a high ratio watershed/reservoir and the provision of particulate material by tributaries (Grande, Chico rivers, and Las Animas stream) and hypolimnetic fluxes; both reasons, as says by Serrya (1976 apud Alvarez-

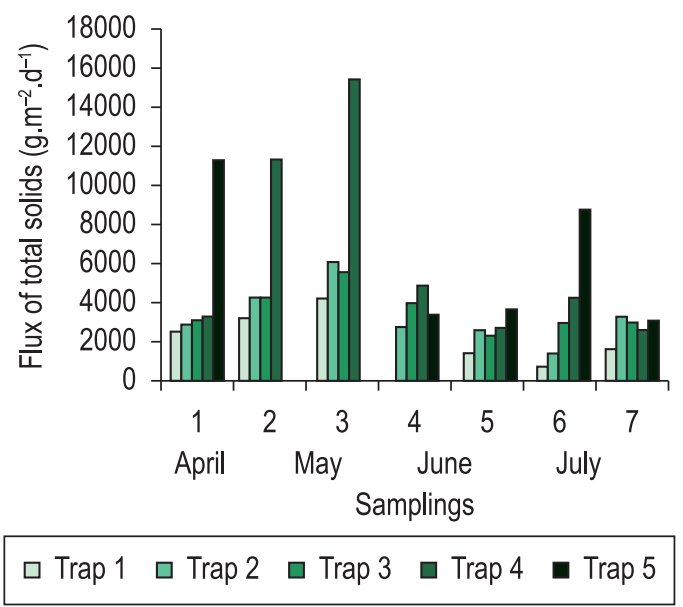

(a)

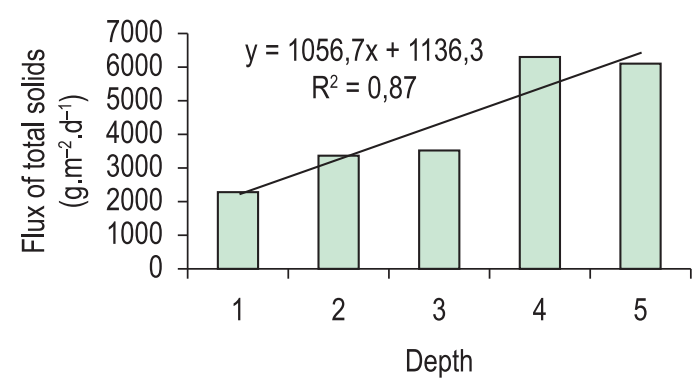

(b)

Figure 2. Variation of the flux of total solids between sampling (a) and with the depth of the traps (b). 
Cobelas et al., 1993), to enter large amounts of organic and inorganic materials which are added to the autochthonous material. Despite this, organic matter decomposing falls while reducing

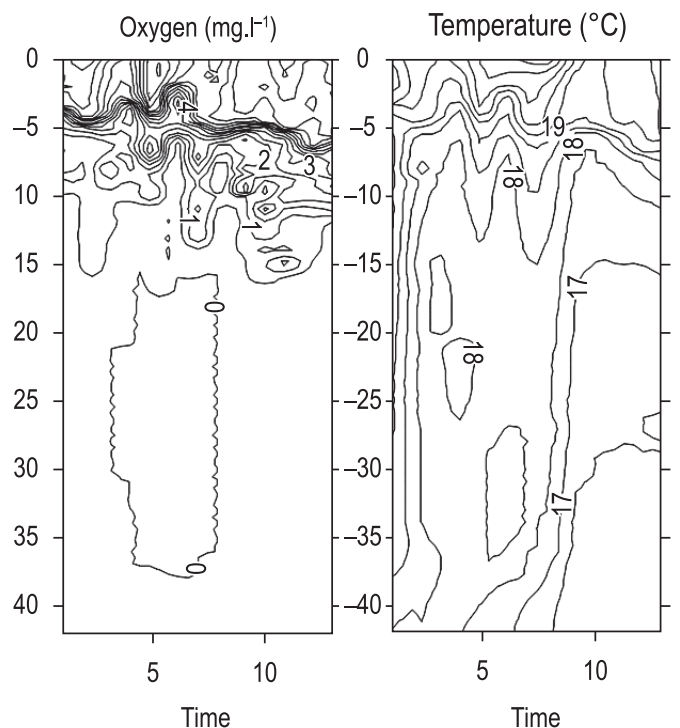

Figure 3. Water temperature and oxygen variation in the time.

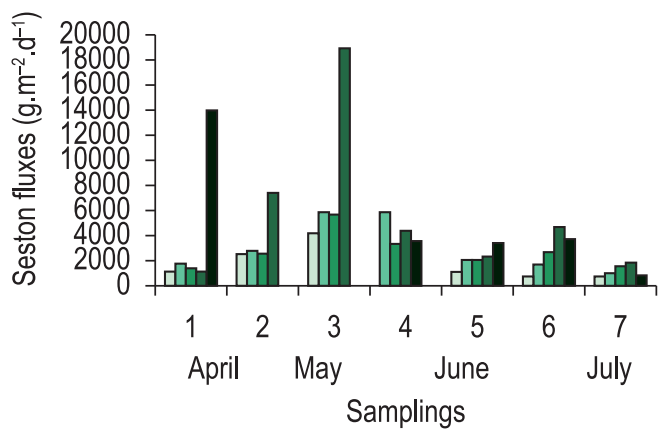

$\square \operatorname{Trap} 1 \quad \square \operatorname{Trap} 2 \quad \square \operatorname{Trap} 3 \quad$ a Trap $4 \quad$ Trap 5

(a)

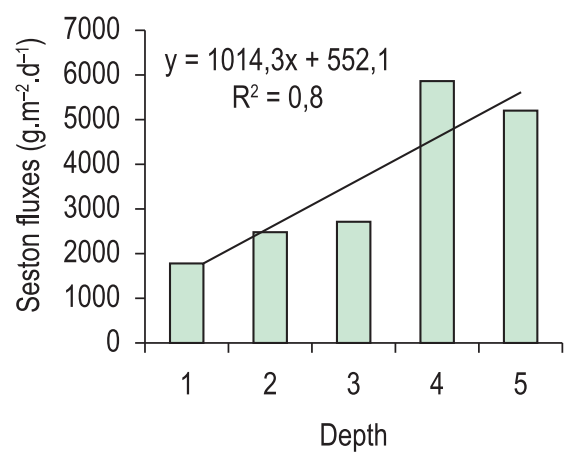

(b)

Figure 4. Variation of the seston flux between sampling (a) and with the depth of the traps (b).

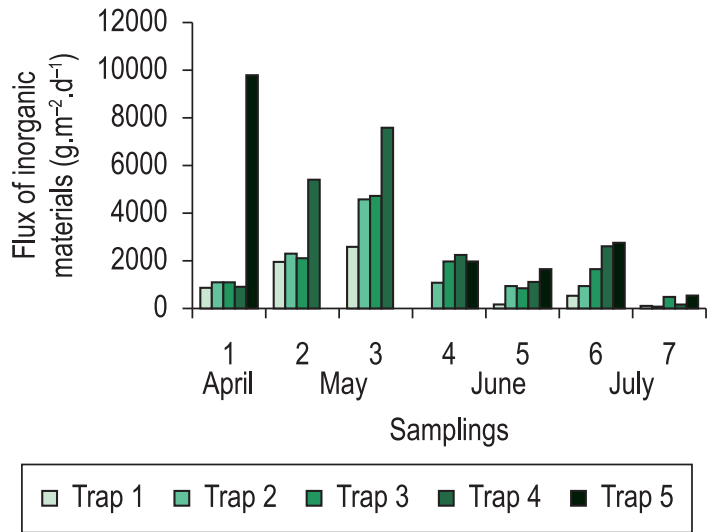

(a)

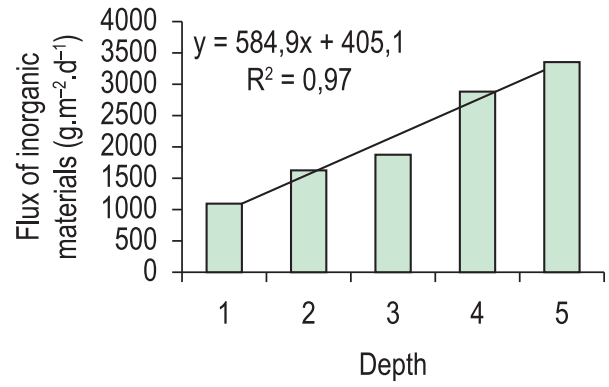

(b)

Figure 5. Variation of the flux of inorganic materials between sampling (a) and depth of the traps (b).

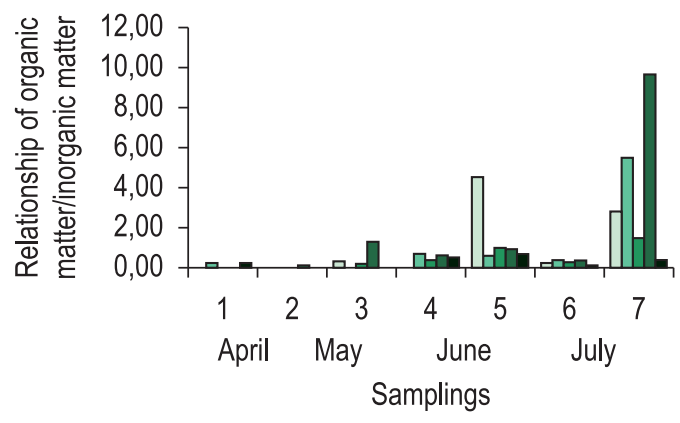

$\square \operatorname{Trap} 1 \square \operatorname{Trap} 2 \square \operatorname{Trap} 3 \square \operatorname{Trap} 4 \square \operatorname{Trap} 5$

(a)

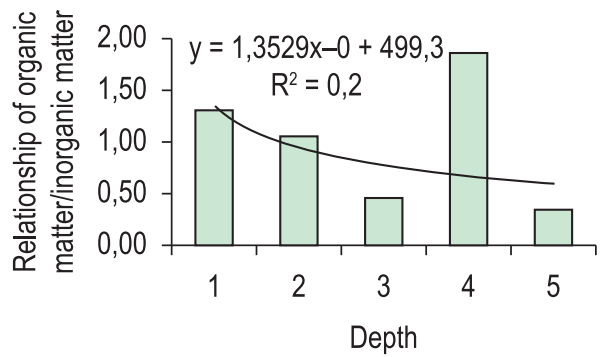

(b)

Figure 6. Variation of the relationship of organic matter/ inorganic matter between sampling (a) and depth of the traps (b). 


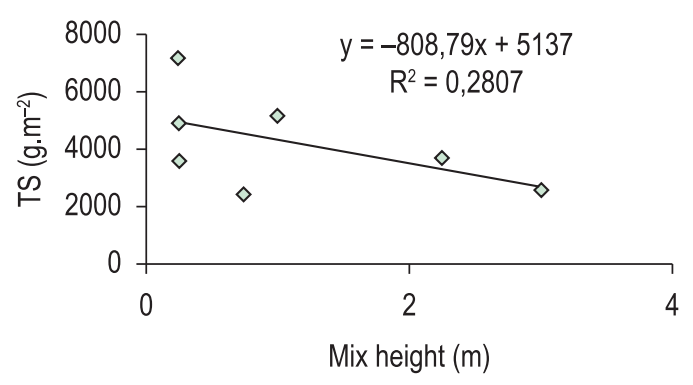

(a)

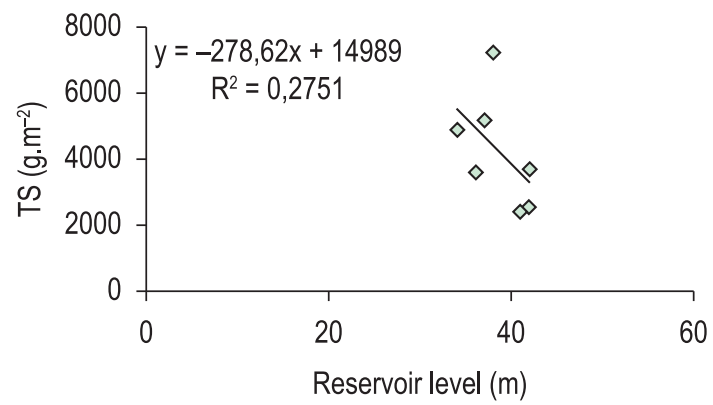

(c)

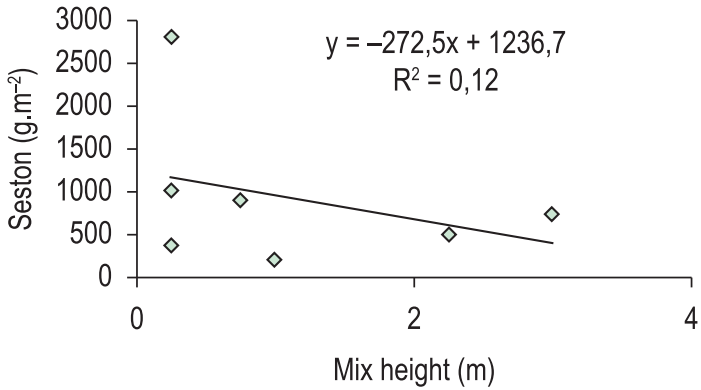

(b)

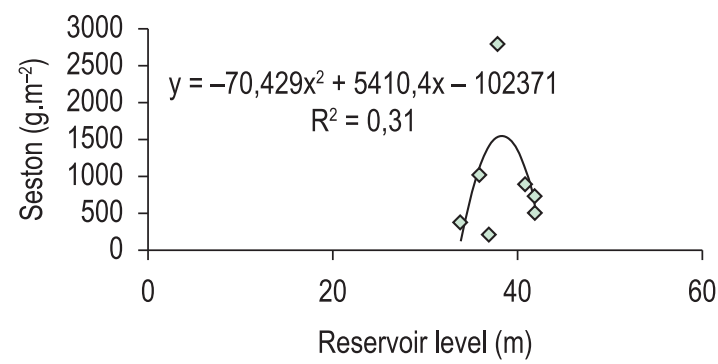

(d)

Figure 7. Relationship of the materials fluxes with the mixture height and with the reservoir level in the time of sampling (a-c) and depth of the traps (b-d).

the number of cells that eventually come to sinking traps (Reynolds et al., 1982), which is more common when water is warmer and oxygenated.

This author mentioned that the sediment particulate fraction is the main source of energy for microorganisms and benthic organisms. Moreover, in the lakes of lower primary production this fraction is predominantly inorganic (Esteves, 1998). This was reflected in the low values of chlorophyll a and productivity $\left(24.1 \mu \mathrm{g} . \mathrm{l}^{-1}, 0.32-0.67 \mathrm{mgO}_{2} . .^{-1}\right)$ in this reservoir area. These features allow us to identify the dam zone Rio Grande II reservoir as an oligotrophic one. Most of the trapped seston (74\%) belongs to the inorganic range, and presents very similar tendency to the behavior of total solids at temporal and vertical level.

For temperate regions is reported a high association between reservoir level and sedimentation rate (Bloesch and Uehlinger, 1986; Rowan et al., 1992; Gibson and Guillot, 1997). This research evaluated the relationship of the sedimentation rate with the height of the mixed layer and the level of the reservoir. In both cases, the correlation was very low and no significant. The high percentage of unexplained variability can be attributed to the hypolimnetic fluxes associated with the hydraulic system, which generates overtrapping material and sediment resuspension (Bloesch and Burns,
1980; Hilton, 1986; Thorton et al., 1990). It was evident throughout this investigation that the higher values of sediments and seston collected were found between fourth and fifth traps (the deepest ones). In addition, the inorganic material prevailed at the time and depth, except towards the end of the surveys. According to Avnimelech and Vodka (1988) the biggest problem associated with the technique of traps sedimentation is the uncertain extent of the effects of resuspension. Edmonson (1971 apud Maricato, 1994) recommends studies below the epilimnion or close to the bottom since the intermediate depths (hypolimnion) show little variation in the amount of material collected in connection with those near the bottom.

In tropical reservoirs had been reported relation between wind speed and seston sedimentation (Leite et al., 2000). In Rio Grande II reservoir this tendency was confirmed and too the increase in seston concentration in the deepest traps because of hypolimnetic fluxes and resuspended materials.

The SRP sedimentation rates in the first two traps were very low in comparison with the three deepest, with a ratio of $1: 23$, which is indicative of a high mineralized of settling material and the dominance of inorganic material in the hypolimnetic fluxes. Vargas and Ramírez (2001) found the same pattern in a reservoir that takes water by pump. These 
authors attribute these results to the effects of flow (pumping water), the organic matter mineralization and the possible death of bodies trapped and their subsequent decomposition, which increases the mineralization. Galvez et al. (1989) argued that when the hypolimnion is anoxic, mineralization at thermocline level is the highest as well as the regeneration of nutrients. This could happen in the first traps which were nearest the thermocline, since in these traps there were higher concentrations of dissolved oxygen and a statistical behavior different from the other three. This situation could allow to degradation processes continue collecting in these traps highly mineralized material, while in the traps below, the low levels of oxygen favored the higher concentrations of phosphorus.

For small lakes, Hilton (1986) proposed 10 mechanisms to explain the sediments distribution. Considering these mechanisms, we considered that in the reservoir, the major phenomena that control sedimentation are the riverine plume sedimentation, the continuous and complete mixing, and the current erosion / deposition phenomenon. For a better understanding of the dynamics of sediments in the reservoir would be useful to look at the bathymetric survey and calculate the areas of erosion, transport and deposition of materials, in addition to other morphometric variables of great limnological interest.

The question now is why after thermocline establishment, particles flux decreases, if several authors have found that stratification processes accelerating sedimentation and total fluxes of sestonic material? (Karl et al., 1988; Galvez et al., 1989; Callieri et al., 1991; Alvarez-Cobelas et al., 1993; Maricato, 1994; Wetzel, 2001). As has been raised previously, the sestonic material collected in traps is mainly allochthonous, and this depends on the loads entering the reservoir by the three tributaries and of the period of greatest stratification. When levels of water in the tributaries lowered water average temperature increased, generating a net decrease in the inflow of materials because an increase in the mineralization of organic matter. Another response to this question is the relationship with operational regimen of the reservoir, because in Rio Grande II toward end of survey, outflow and seston decreased too. This meaning relationship between seston material and residence time.

From the point of view of the sestonic material decomposition, in the first two samples, the organic fraction of the settling material was zero in the fourth trap; this indicates that the mineralization process was complete. The deepest samples, showed that on the second trap was achieved the greatest reduction of the organic fraction (without reaching levels above); after this trap, seston concentration was increased because hypolimnetic fluxes which increase the organic fraction of the material stored in traps. This result is in line with statistical analysis which showed no significant differences between depths for the concentration of organic matter. Fallon and Brock (1980) argued that there is a great diversity of particulate material in seston and that differences in the organic content of the materials in the traps can be related to seston a preferential sedimentation and decaying in them.

Finally, it could be argued that the main factors affecting the deposition of seston in the Rio Grande II reservoir are the mineralization of organic matter, which in turn depends on the water temperature, the concentration of dissolved oxygen and the seston organic fraction; important factors were too wind, morphometry and the retention time of the reservoir. This system is composed of three branches and each one receive a tributary, which eventually flow into the reception tower, creating permanent hypolimnetic fluxes and resuspended material in the system, since the average total solids collected in traps compared to the average of entering tributaries, have a ratio of $70: 1$.

\section{Conclusions}

Sedimentation experiments allow us to conclude that the mineralization in some samples was $100 \%$, most of the sestonic fluxes corresponds to inorganic fraction which fluctuates over time and across depths. The settling sestonic material is mainly allochthonous; for this reason, didn't show a significant relationship between reservoir level and the height of mixing respect to the sedimentation rates and the fraction total sestonic.

We conclude that the first three traps only collected particles to be settled from the water column; the traps located near to the bottom also collected resuspended particles from the bottom of the reservoir and / or transported by hypolimnetic currents. We think that the amount of seston depends of wind and the reservoir level.

Next works would be of great interest to evaluate sedimentation rates in horizontal and vertical level, with an emphasis on the area of the reception tower; besides this, to evaluate clearly the contribution of the sediment resuspended. 


\section{References}

ALVAREZ-COBELAS, M., VELASCO, DJ. and RUBIO-OLMO, A. 1993. Settling seston in a hypertrophic lake. Archiv für Hydrobiologie, vol. 127, p. 327-343.

American Public Health Association - APHA, American Water Works Association and Water Pollution Control Federation. 1995. Standard methods for the examination of water and wastewaters. 18th ed. Baltimore: United Book Press. 1268 p.

AVNIMELECH, Y. and VODKA, M. 1988. Accumulation of nutrients in the sediments of Maaleh Hakishon reclaimed effluents reservoir. Water Research, vol. 22, p. 1437-1442.

BLOESCH, J. and BURNS, M. 1980. A critical review on sediment traps technique. Schweiz. Z. Hydrobiologia, vol. 42, p. 15-55.

BLOESCH, J. and UEHLINGER, G. 1986. Horizontal sedimentation differences in a eutrophic Swiss lake. Limnology \& Oceanography, vol. 31, p. 1094-1109.

BLOMQVIST, S. and HÅKANSON, L. 1981. A review on sediment traps in aquatic environments. Archiv für Hydrobiologie, vol. 91, p. 101-132.

CALLIERI, C., BERTONI, R., DE MARCO, C. and CONTESINI, M. 1991. Settling flux and sinking velocity of seston in lago di Mergozzo (Nortern Italy) and influence of microbial activity on the descomposition of entrapped organic material. Hidrobiologia, vol. 213, p. 155-165.

ESTEVES, FA. 1998. Fundamentos de limnología. Rio de Janeiro: Interciência, FINEP. 545 p.

FALLON, RD. and BROCK, TH. 1980. Planktonic blue - green algae: production, sedimentation, and decomposition in lake Mendota, Wisconsin. Limnology \& Oceanography, vol. 25, p. 72-88.

GALVEZ, JA., NIELL, FX. and LUCENA, J. 1989. Seston vertical flux model for an eutrophic reservoir. Archiv für Hydrobiologie, vol. 33, p. 9-18.

GARDNER, WD. 1977. Fluxes, dynamic and chemistry of particulates in the ocean. M.I.T./Woods Hole Oceanographic Institution, Joint Program in Oceanography. 405 p. [Ph. D Thesis].

GIBSON, CE. and GUILLOT, J. 1997. Sedimentation in a large lake: the importance of fluctuation in water level. Freshwater Biology, vol. 37, p. 597-604.

HÅKANSON, L. 1975. A bottom sediment trap for recent sedimentary deposits. Limnology \& Oceanography, vol. 21, p. 170-174.

HÅKANSON, L. and JANSSON, M. 2002. Principles of lake sedimentology. New Jersey: Blackburn Press. $316 \mathrm{p}$.

HARGRAVE, BT. and BURNS, NM. 1979. Assessment of sediment trap collection efficiency. Limnology \& Oceanography, vol. 24, p. 1124-1135.
HILTON, J. 1986. The dominant processes of sediment distribution and focusing in samll eutrophyc monomictic lake. Limnology \& Oceanography, vol. 31, p. 125-135.

IMBODEN, DM. and LERMAN, A. 1978. Chemical models of lakes. In LERMAN, A., ed. Lakes: chemistry, geology, physics. London: Springer. p. 341-356.

KARL, DM., KNAUER, GG. and MARTIN, JH. 1988. Downward flux of particulate organic matter in the ocean: a particle decomposition paradox. Nature, vol. 22, p. 438-441.

LEITE, MA., ESPÍNDOLA, ELG. and CALIJURI, MC. 2000. Tripton sedimentation rate in the Salto Grande reservoir (Americana, SP, Brazil). Acta Limnologica Brasiliensia, vol. 12, p. 63-68.

MACKERETH, SJ., HERON, J. and TALLING, JF. 1978. Water analysis; some revised methods for limnologist. London: Titus Wilson and Sons. 172 p. Freshwater Biological Association, Scientific Publications, no. 36.

MARGALEF, R. 1983. Limnología. Barcelona: Edic. Omega. 1010 p.

MARICATO, FE. 1994. Caracterzaçao fisico - química e sedimentaçâo nos regiones de desembocadura dos ríos Paranapanema e taquari e no reservatório de Juruminim (Alto Paranapanema - SP). São Carlos: Escola de Engenharia de São Carlos. 150 p. [Master Thesis].

MITAMURA, O., SAIJO, Y., HINO, K. and BARBOSA, RF. 1990. The significance of regenerated nitrogen for phytoplankton productivity in Lakes Dom Helvécio, Jacaré and Carioca. In BOZELLI RL., ESTEVES FA. and ROLAND F., ed. Limnological Studies on the Rio Doce Valley Lakes, Brazil. Rio de Janeiro: Ed. UFRJ/ SBL. p. 129-153.

MONTOYA-MORENO, Y. and RAMÍREZ, JJ. 2007. Flujos de mineralización en el embalse tropical Río Grande II (Antioquia, Colombia). Limnética, vol. 26, p. 36-52.

NIÑO, JP. and GUILLOT, G. 2004. Variación espaciotemporal de las tasas de sedimentación del nitrógeno y fósforo en el seston del embalse del Neusa, Colombia. Actualidades Biológicas, vol. 80, p. 39-49.

PAERES, A.M. and RIVERA, C.A. 2004. Producción primaria fitoplanctónica y sedimentación total del humedal Juan Amarillo (Bogotá, Colombia). In VI Seminario Colombiano de Limnología. Montería, Colombia.

PENNINGTON, W. 1974. Seston and sediment formation in five lakes District lakes. Journal of Ecology, vol. 62, p. 215-251.

RAMÍREZ, JJ. and NOREÑA, JF. 2001. Comportamiento de las tasas de sedimentación del material sestónico en dos periodos climáticos contrastantes en un lago urbano raso: laguna del parque Norte, Medellín 
(Colombia). Actualidades Biológicas, vol. 74, p. 65-74.

REYNOLDS, CS. 1984. The ecology of freshwater phytoplankton. Cambridge, England: Cambridge Univ. Press. $384 \mathrm{p}$.

REYNOLDS, CS., MORISON, HR. and BUTTERWICK, C. 1982. The sedimentary flux of phytoplankton in the south basin of Windemere. Limnology \& Oceanography, vol. 26, p. 1162-1175.

ROWAN, DJ., KALF, J. and RASMUSSEN, JB. 1992. Estimating the mud depositation boundary depth in lakes from wave theory. Canadian Journal of Fisheries and Aquatic Sciences, vol. 49, p. 2490-2497.

THORNTON, KW., KIMMEL, BL. and PAYNE, FE. 1990. Reservoir Limnology: ecological perspectives. New York: John Wiley \& Sons. 246 p.
VARGAS, RA. and RAMÍREZ, JJ. 2002. Variación espacio - temporal de las tasas de sedimentación del material sestónico en un embalse tropical de alta montaña: represa La Fe, El Retiro, Antioquia, Colombia. Actualidades Biológicas, vol. 77, p. 163-170.

WASSMANN, P., STIINA, A. and LINDAHL, O. 1990. Resuspension-characterization of possible sources. In Procedings of the Symposium in Sediment Traps in Marine Ecological Research and Monitoring. Finland: Tvarrminne Zoological Station. 307 p.

WETZEL, RG. 2001. Limnology: lake and river ecosystems. 3th ed. San Diego: Academic Press. $1006 \mathrm{p}$.

Received: 05 June 2009 Accepted: 03 November 2010 